Journal of Research in Interprofessional

Practice and

Education

Vol. 2.1

July, 2011

\section{The Development of Competencies in Interprofessional Healthcare for Use in Health Sciences Educational Programs}

\author{
Jayshiro Tashiro, PhD, RN; Carolyn Byrne, PhD, RN; Lisa Kitchen, MSc; \\ Ellen Vogel PhD, RD, FDC; Carrie Bianco, MScPT
}

\begin{abstract}
Background: The Health Education Technology Research Unit (HETRU) at the University of Ontario Institute of Technology (UOIT) has developed an interprofessional framework for use as a learning map to create computer-based simulations that can automatically assess interprofessional competencies of undergraduate health sciences students.

Methods: Our interprofessional competency framework was developed through an iterative process of competency mapping. Each iteration involved: 1) a literature review of interprofessional competencies, 2) the mapping of these competencies within a meaningful taxonomy, and 3) the review of the mapping by an expert panel of educators and clinicians.

Findings and Conclusions: After three iterations, the research team developed a competency taxonomy that mapped interprofessional competencies from our literature reviews into six competency domains and three cross-cutting themes for each domain. The competency matrix was then used as a learning map to define learning resources related to interprofessional education and learning activities associated with such resources to help students develop competencies in interprofessional healthcare planning and delivery. Interactive, computer-based clinical simulations were then developed to portray opportunities in which the learning resources and activities could be explored and to provide more realistic exposure to complexities in healthcare planning and delivery.

Keywords: Interprofessional education; Health sciences; Competencies; Technology
\end{abstract}

\section{Introduction}

A broad base of recent work has provided new models for exploring the complexity of factors leading to the ineffective articulation of healthcare services [1-6]. Worldwide, healthcare services could be improved by providing interprofessional, collaborative, patient-centred care that improves patient outcomes while reducing healthcare costs [7-14]. Yet, despite the diverse and extensive literature on change management and human resources management, few empirically based models provide the breadth and depth necessary to deal with the complexities of transforming current healthcare systems into care planning and delivery systems that are interprofessional, evidence-based, and cost-effective.

Interestingly, the concept of patient-centered care [15] or relationship-centered care [16] has emerged as a reaction against the conventional biomedical model of care [17]. According to Herbert [18], collaborative, patient-centred practice is:

a practice orientation, a way of health care professionals working together and with patients and their families. It involves the contin- 
64

Development of Competencies in IP Healthcare

Tashiro, Byrne, Kitchen, Vogel, \& Bianco

Journal of Research in Interprofessional Practice and Education

Vol. 2.1

July, 2011 uous interaction of two or more professionals or disciplines organized into a common effort to explore common issues with the best possible participation of the patient. It is designed to promote the active participation of each discipline in patient care. It enhances patient and family centered goals and values, provides mechanisms for continuous communication among caregivers and patients, optimizes staff participation in clinical decision making within and across disciplines, and fosters respect for the contributions of all professionals, the patient, and their caregivers. (p. 2)

Exploring new ways of providing care has led to the resurgence of interest in interprofessional healthcare collaboration. This interest is due to health system renewal, emerging health and human resource issues, and continuity and co-ordination of care [10]. The belief underlying the support for interprofessional care is that working with members of other professions will result in the provision of more highly integrated, patient-centred care; in addition, the complexity of most health problems requires a co-ordinated approach to understanding and management [19]. Although advocates for interprofessional education have tried to move forward in implementing this approach, one of the most difficult arenas to establish interprofessional education has been in undergraduate (or pre-licensure) health sciences.

In 2003, at the First Ministries Accord on Health Care Renewal in Canada, one of the goals put forward was to achieve an integrated and interdisciplinary approach to primary care [20]. One suggestion for meeting this goal was to change the way health professionals were educated; hence, an initiative on professional education for collaborative patient-centred practices was launched. Since then, other interprofessional initiatives have been launched within the provinces across Canada [10,21].

A Health Canada review of interprofessional education [10] found some evidence that post-licensure professional collaborations can improve healthcare processes and outcomes in some areas of geriatric care [22,23], congestive heart failure management [24], and neonatal care [25], but no reliable evidence on the effectiveness of interprofessional education at the undergraduate or pre-licensure level could be found. One of the notions supporting interprofessional education at the undergraduate level is that it may assist students in appreciating various roles within healthcare, increase comfort in working with other health professionals, and hence increase post-licensure interprofessional practice.

Although there are issues that cause barriers to interprofessional learning at the pre-licensure level, such as basic differences in curriculum structures, lack of support, lack of comfort in teaching across disciplines, and financial constraints [26], one of the major difficulties is a clear understanding of what competencies should be emphasized and measured in an undergraduate interprofessional curriculum [7]. Certainly, competencies are often used within specific professions to create standards within the profession [27,13]; however, interprofessional competencies have been difficult to agree upon across disciplines and practice settings. 
65

Development of Competencies in IP Healthcare

Tashiro, Byrne, Kitchen, Vogel, \& Bianco

Journal of Research in Interprofessional Practice and Education

Vol. 2.1

July, 2011

\section{Literature Review}

Barr $[28,29]$ identified eight core competencies that began to address the knowledge, clinical, technical, and communication competencies that health professionals need to possess to provide interprofessional care. However, specific observable and measurable competencies were not clearly delineated.

A review of the literature suggests that actual delineation of competencies began in the United States prior to similar work in Canada. The American Council on Pharmaceutical Education [30], the Pew Health Professions Committee [31], the United States Institute of Medicine [13], and the University of Minnesota [32] had begun work on defining and delineating interprofessional competencies for healthcare planning and delivery. In Canada, Health Canada [10], the Canadian Interprofessional Health Collaborative [CIHC] [7], HealthForceOntario [11], Barker and Oandasan [8], and Barker, Bosco, and Oandasan [9] described the need for interprofessional competencies and provided strategies to move toward improved interprofessional care.

More recently, researchers at the University of British Columbia [33] developed what they called a "universally applicable framework" for interprofessional competencies, building on the foundation of the Guided Interprofessional Field Study [34]. We also note that at the University of Washington, the Center for Health Sciences Interprofessional Education (CHSIE) developed an interesting approach that delineated core interprofessional competencies and then mapped competency areas to learning objectives, learning objectives to learning opportunities, and coupled learning opportunities to objective Structured Clinical Examinations for pharmacy students [35]. University of Washington researchers and educators also developed and evaluated team simulations to assess interprofessional skills [36].

Our overarching goal was to create a framework of competencies that could be integrated sensibly into interprofessional educational initiatives and into professional development and continuing education programs. Initial efforts reported in the literature were either too narrow in scope or too conceptual in nature to successfully advance our work. Subsequent work, such as the University of Washington efforts $[35,36]$, began a more detailed development of learning maps. We acknowledge this prior excellent work and especially the role of CIHC [7] in pulling together Barr's [28,29] work along with the American and Canadian works mentioned above. However, from our perspective, we noted a series of gaps in the current literature. For example, authors do not report a broadly based interprofessional core competency framework and/or how to operationalize such frameworks into sensible curricular structures with complete mapping of competencies to learning objectives to learning opportunities to authentic learning assessments. Furthermore, little attention was given to some important theoretical frameworks related to development of conceptual and performance competencies $[37,38]$.

A very nice body of work emerged from the Office of Interprofessional Education at the University of Toronto [39]. This group identified three domains of interprofessional care, as well as several respective sub-domains: 
Development of Competencies in IP Healthcare

Tashiro, Byrne, Kitchen, Vogel, \& Bianco

Journal of Research in Interprofessional Practice and Education

Vol. 2.1

July, 2011

\section{Journal of Research in Interprofessional Practice and Education}

\author{
KNOWLEDGE \\ - roles of other health professionals \\ SKILLS \\ - communicating with others \\ - reflecting upon my role and the roles of others \\ ATTITUDES \\ - mutual respect \\ - willingness to collaborate \\ - openness to trust
}

The Office of Interprofessional Education also began to work on identifying observable and measurable competencies as well as thinking through curricular change that would lead to learning activities that were likely to help inculcate competency development and valid learning assessments that demonstrate a competency had been achieved. We hope to add to this emerging body of work by completing a relatively simple convergent analysis that sorted identified competencies into domains and cross-cutting themes.

\section{Purpose}

This research project took place at the University of Ontario Institute of Technology (UOIT) in the Health Education Technology Research Unit (HETRU). UOIT is currently Canada's only laptop-based university, located in Oshawa, Ontario. HETRU's vision is the evidence-based use of technology in healthcare, education, and inter-

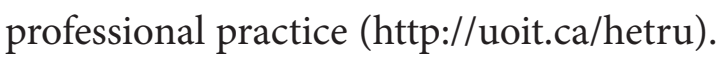

The purpose of this study was to identify measurable interprofessional competencies for undergraduate health sciences students that can be used in teaching related to interprofessional care. The research team took a novel approach in a preliminary effort to synthesize earlier work completed by the CIHC [7] and the Office of Interprofessional Education at University of Toronto [39]. We reviewed Barr's $[28,29]$ initial framework of competencies, which were widely accepted as representing a reasonable framework for interprofessional practices. Subsequently, we searched a broad base of prior and more recent literature to see if we could elaborate Barr's framework by identifying both domains of competencies as well as crosscutting themes cutting through domains. We were interested in identifying competencies that could be taught and measured both within the clinical setting and in the classroom in undergraduate health sciences programs.

This interdisciplinary research program was planned in several phases. Phase one was the identification of clear competencies that could be understood and measured both by teachers and students. Phase two was the development of interprofessional scenarios and simulations that could be used with students to measure interprofessional competencies. Phase three will be the actual testing of students' interprofessional competencies in a simulated setting. This article reports on phase one of this work-developing competencies-and also addresses some of the work completed thus far in phase two. 
67

Development of Competencies in IP Healthcare

Tashiro, Byrne, Kitchen, Vogel, \& Bianco

Journal of Research in Interprofessional Practice and Education

Vol. 2.1

July, 2011

\section{Methods}

Ethical approval was obtained by the Research Ethics Board at UOIT. The development of interprofessional competencies occurred in two stages. In the first stage the literature on interprofessional competencies was reviewed and core competencies were indentified. An extensive literature search was conducted, in addition to exploring ongoing research by UOIT faculty members and their collaborators, and our practice partners. In the second stage, an Advisory Board and an Extramural Review Panel were involved in an iterative review and critique of the competencies identified in stage 1.

Members of the Advisory Board and Extramural Review Panel were selected based on their knowledge, experience, and expertise in the area of interprofessional education. Members were selected to ensure that the Advisory Board and Extramural Review Panel included broad representation from a variety of health sciences academics, professionals, and practicing clinicians (e.g., family physician, nurse practitioner, mental health clinician, HIV/AIDS clinician). Members of both groups had a demonstrated track record in the use of a highly collaborative approach, which resulted in a smooth transition of reaching agreement during the revision process for the development of the Core Competency Framework. Since individuals were providing feedback based on specific areas of professional interest and/or expertise, members of both the Advisory Board and Extramural Review Panel were very respectful of the process, thus allowing the Framework to move forward in the review process with tremendous ease. Once feedback was received from each group, the research team incorporated suggestions into a newly revised Framework. This document was then given to each group for further feedback until all members came to a consensus for the final version of the Framework. This process occurred over several months.

Seven individuals formed the Advisory Board, with backgrounds in family medicine, nursing, psychology, physiotherapy, speech language pathology, dietetics, and medical sociology. Advisory Board members were given the first version of the Interprofessional Core Competency Framework, which was created in stage 1. They were each asked to provide an independent written critique containing constructive feedback and identifying areas for improvement. Based on the feedback received, revisions were compiled into the second version of the Interprofessional Core Competency Framework. This second version was sent to Advisory Board members for final comments and suggested revisions. Consensus was reached during both individual and group meetings of the Advisory Board, facilitated by HETRU researchers. The revised consensus second version was then sent to an Extramural Review Panel.

The Extramural Review Panel consisted of eight individuals with backgrounds in family medicine, IPE-related research, nursing, mental health, and geriatric care. Following the same review process as used for the Advisory Board, the Extramural Review Panel sent comments, concerns, and suggested revisions to the HETRU researchers. The Extramural Review Panel critiques were used to create a third version of the Core Competency Framework. This third version was sent to the 


\section{JRIPE}

68

Development of Competencies in IP Healthcare

Tashiro, Byrne, Kitchen, Vogel, \& Bianco
Journal of Research in Interprofessional Practice and Education

Vol. 2.1

July, 2011
Journal of Research in Interprofessional Practice and Education

Extramural Review Panel for final review and discussion. Consensus was reached through individual and group meetings facilitated by the HETRU researchers, and the revised third version became our current Interprofessional Core Competency Framework.

We also note that the Extramural Review Panel provided additional input by developing scripts for the second phase of this study, namely the development of educational simulations to improve interprofessional education. This process added an additional level of discussion and consensus building about how well the Core Competency Framework worked as a set of observable and measureable conceptual and performance competencies.

\section{Developmental Analysis}

The first version of an Interprofessional Core Competency Framework combined elements of Barr's [28,29] collaborative competencies and competencies identified within the literature reviewed by the CIHC [7]. We collapsed Barr's [28,29] competencies into three cross-cutting themes for each of the seven core competency domains that the CIHC [7] found repeatedly mentioned in the literature. This yielded the competency framework shown in Table 1. This framework was a starting point for an Interprofessional Core Competency Framework. For example, Cell A would represent learning activities with a focus on problem solving in the context of the cross-cutting theme of roles and responsibilities. Cell B represents learning activities with a focus on patient-centred care in the context of the complexities of professional dynamics among team members (e.g., tolerating differences, facilitating interprofessional care conferences, entering into interdependent relations with other professionals).

\section{Table 1}

\section{Basic framework for "Interprofessional Core Competencies Version 1.0"}

\begin{tabular}{|l|c|c|c|}
\hline \multirow{2}{*}{\multicolumn{1}{c|}{ Core }} & \multicolumn{3}{c|}{ Cross-cutting themes } \\
\cline { 2 - 4 } & Roles and responsibilities & Assessing and planning & Professional dynamics \\
\hline 1. Problem solving & A & & \\
\hline 2. Decision making & & & \\
\hline 3. Respect & & & \\
\hline 4. Communications & & & \\
\hline 5. Shared knowledge & & & \\
\hline 6. Patient-centred care & & & B \\
\hline 7. Working as a team & & & \\
\hline
\end{tabular}

This framework was then shared with the interprofessional Advisory Board and was rigorously reviewed. Reviews were returned and a revised competency framework was developed, using a re-examination of the literature as well as written cri- 


\section{JRIPE}

69

Development of Competencies in IP Healthcare

Tashiro, Byrne, Kitchen, Vogel, \& Bianco
Journal of Research in Interprofessional Practice and Education

Vol. 2.1

July, 2011 tiques from the Advisory Board. The revisions were compiled into a new document, "Interprofessional Core Competencies Version 2.0." The major revisions included combining the cross-cutting themes of roles and responsibilities with the theme of professional dynamics. This revision left two cross-cutting themes, but the reviewers argued convincingly that patient-centred care be removed from the seven core competency domains and be added as a cross-cutting theme. The basic framework for the revised competency framework is shown in Table 2. Cells with an "*" indicate changes from Version 1.0 in the terms used to describe core competencies domains and cross-cutting themes.

In our revised competency framework, Cell A would now be learning a set of competencies with a focus on problem solving in the context of the cross-cutting theme of professional dynamics (including roles and responsibilities). Cell B relates to working as a team in the context of assessing and planning, inclusive of assessment and planning activities that include teamwork activities necessary for assessing patient needs and planning for care. The column of cells under patient-centred care now includes competencies specific to interprofessional collaborative patientcentred care that fall in each of the six core competency domains.

Table 2

\section{Basic framework for "Interprofessional Core Competencies Version 2.0"}

\begin{tabular}{|l|c|c|l|}
\hline \multirow{2}{*}{\multicolumn{1}{|c|}{$\begin{array}{c}\text { Core } \\
\text { competencies domains }\end{array}$}} & $\begin{array}{c}\text { Professional dynamics } \\
\text { (including roles and } \\
\text { responsibilities) }\end{array}$ & Assessing and planning & Patient-centred care* \\
\hline 1. Problem solving & A & & \\
\hline 2. Decision making & & & \\
\hline 3. Respect & & & \\
\hline 4. Communications & & & \\
\hline 5. Shared knowledge & & & \\
\hline 6. Working as a team & & B & \\
\hline
\end{tabular}

The Version 2.0 competency framework was then reviewed by the interprofessional Advisory Board and an Extramural Review Panel. A variety of suggestions were made. We contextualized these suggestions in the research literature we had reviewed as well as in literature suggested by the reviewers. This resulted in Version 3.0 of the competency framework. In Table 3, we show a basic matrix that simplifies the Interprofessional Core Competency Framework. Cells with an " *" indicate changes from Version 2.0 in the terms used to describe core competencies domains and cross-cutting themes. 


\section{JRIPE}

70

Development of Competencies in IP Healthcare

Tashiro, Byrne, Kitchen, Vogel, \& Bianco
Journal of Research in Interprofessional Practice and Education

Vol. 2.1

July, 2011
Table 3

\section{Basic framework for "Interprofessional Core Competencies Version 3.0"}

\begin{tabular}{|c|c|c|c|}
\hline \multirow[b]{2}{*}{$\begin{array}{c}\text { Core } \\
\text { competencies domains }\end{array}$} & \multicolumn{3}{|c|}{ Cross-cutting themes } \\
\hline & Team functioning* & $\begin{array}{l}\text { Assessing, planning, } \\
\text { and intervention* }\end{array}$ & Patient-centred care \\
\hline 1. Problem solving & A & & \\
\hline 2. Decision making & & & \\
\hline 3. Respect & & & \\
\hline 4. Communications & & & \\
\hline 5. Shared knowledge & & & \\
\hline 6. Team Participation* & & B & \\
\hline
\end{tabular}

Tables 4 through 9 illustrate each core competency domain with the respective competencies under the cross-cutting themes. As you view these tables, you will note references to competencies that had been developed and published in earlier competency frameworks for interprofessional care and education. We encourage readers to look at these earlier references and to evaluate how our proposed competency framework better contextualizes how, when, and why a competency is expressed during actual care planning and delivery. Specifically, the principal difference between our competency framework and prior published frameworks is the use of a taxonomy of competency domains articulated with cross-cutting themes. Certainly, most development of competency frameworks (in any discipline or interdisciplinary area) involves discussions about what we call "lumping or splitting" activities related to a competency area, which the peer review panels engaged in for our work. However, we feel the broad representation of disciplines among the panel participants provided a rigorous
Legend for Tables 4 to 9 References

\begin{tabular}{|l|l|}
\hline $\begin{array}{l}\text { Abbreviated } \\
\text { Name: }\end{array}$ & Full Name: \\
\hline HF0 & HealthForceOntario \\
\hline IOM & Institute of Medicine \\
\hline Pew & The Pew Research Centre \\
\hline UofT & University of Toronto \\
\hline UMinn & University of Minnesota \\
\hline
\end{tabular}

Note: Competencies without an identified source were developed by the Advisory Board and Extramural Review Panel. approach to a taxonomically reasonable framework of core competencies.

With the completion of the third review, the first phase of the research program was finished; we now had an interdisciplinary framework with identified core competencies. The Interprofessional Core Competency Framework provides specific competencies under each of the domains and cross-cutting themes. This framework can guide educators and clinicians across disciplines in providing opportunities for students to learn and practice these skills. While some competencies may be learned during work involving multiple professionals who are supposed to be working as an interdisciplinary team (re-learning one's own roles and responsibilities during inter- 
71

Development of Competencies in IP Healthcare

Tashiro, Byrne, Kitchen, Vogel, \& Bianco
Journal of Research in Interprofessional Practice and Education

Vol. 2.1

July, 2011
Table 4

\section{Problem solving}

\begin{tabular}{|l|l|l|}
\hline \multicolumn{3}{|l|}{ Competency domain: 1.0 Problem solving } \\
\hline 1.1 Team functioning & $\begin{array}{l}1.2 \text { Assessment, planning, and inter- } \\
\text { vention }\end{array}$ & 1.3 Patient-centred care \\
\hline $\begin{array}{l}\text { 1.1.1 Knows scopes of professional } \\
\text { practice. (HFO) }\end{array}$ & $\begin{array}{l}\text { 1.2.1 Customizes care and assists in } \\
\text { managing smooth transitions across } \\
\text { settings and over time, even when } \\
\text { health team members are in differ- } \\
\text { ent and sometimes multiple physi- } \\
\text { cal locations. (IOM) }\end{array}$ & $\begin{array}{l}1.3 .1 \text { Involves other health team } \\
\text { members as well as the patient, } \\
\text { their significant others, and commu- } \\
\text { nity members in problem solving } \\
\text { related to planning and implement- } \\
\text { ing care. }\end{array}$ \\
\hline $\begin{array}{l}\text { 1.1.2 Defines responsibilities and } \\
\text { roles of different professions. (HF0 }\end{array}$ & $\begin{array}{l}1.2 .2 \text { Designs and tests interven- } \\
\text { tions to change the process of care, } \\
\text { with the objective of improving } \\
\text { quality. (IOM) }\end{array}$ & $\begin{array}{l}1.3 .2 \text { Assesses and compares current } \\
\text { practices with evidence-based prac- } \\
\text { tices as a means for identifying } \\
\text { opportunities for improvement in } \\
\text { collaborative, patient-centred care. } \\
\text { (I0M) }\end{array}$ \\
\hline $\begin{array}{l}\text { 1.1.3 Contributes to interprofes- } \\
\text { sional problem-solving. (HF0) }\end{array}$ & $\begin{array}{l}\text { 1.2.3 Identifies, refers to, and con- } \\
\text { sults with the most appropriate pro- } \\
\text { fession(s) during the patient care } \\
\text { process. }\end{array}$ & \\
\hline $\begin{array}{l}\text { 1.1.4 Coordinates and integrates } \\
\text { care processes that reflect excel- } \\
\text { lence, continuity, and reliability of } \\
\text { interprofessional care provided. } \\
\text { (I0M) }\end{array}$ & $\begin{array}{l}\text { 1.2.4 Uses interprofessional team } \\
\text { consults or input to develop and } \\
\text { implement assessment, planning, } \\
\text { and interventions during the patient } \\
\text { care process. }\end{array}$ & \\
\hline
\end{tabular}

Note: Competencies without an identified source were developed by the Advisory Board and Extramural Review Panel.

action with other professionals), other competencies certainly lend themselves to providing guidance for designing or promoting interdisciplinary learning encounters. In Tables 4 through 9, each cell was populated with competencies that had already been described in the research literature. Our research team simply collated the many different competencies and organized them within our Core Competency Framework. As noted earlier in the Developmental Analysis section, this was not particularly easy, and there was much debate about where the existing competencies might fit in our framework. However, we also explored how instructional methods and materials could be shaped by advances in cognitive theory and behavioural change [37-45]. With regard to research in the area of cognitive theories, we examined educational strategies and their projected models for competency assessment within more individualistic structured learning (the adaptive character of thought and cognitive load theories) or for what educators call constructivist learning (the cognitive flexibility theory and situated learning theories) $[37,38]$.

In addition, we asked how and why theories of behavioural change should be coupled to cognitive theories within teaching-learning methods and materials in order to understand the development and assessment of conceptual competencies 
72

Development of Competencies in IP Healthcare

Tashiro, Byrne, Kitchen, Vogel, \& Bianco
Journal of Research in Interprofessional Practice and Education

Vol. 2.1

July, 2011
Table 5

\section{Decision making}

\begin{tabular}{|l|l|l|}
\hline \multicolumn{3}{|l|}{ Competency domain: 2.0 Decision making } \\
\hline 2.1 Team functioning & $\begin{array}{l}2.2 \text { Assessment, planning, and inter- } \\
\text { vention }\end{array}$ & 2.3 Patient-centred care \\
\hline $\begin{array}{l}\text { 2.1.1 Demonstrates how to find and } \\
\text { apply current sources of evidence- } \\
\text { based practice for interprofessional } \\
\text { care. (IOM) }\end{array}$ & $\begin{array}{l}2.2 .1 \text { Helps to formulate clear clini- } \\
\text { cal questions and understands team } \\
\text { members' interprofessional responsi- } \\
\text { bilities in searching for and finding } \\
\text { relevant answers to these questions. } \\
\text { (IOM) }\end{array}$ & $\begin{array}{l}\text { 2.3.1 Involves patients and their sig- } \\
\text { nificant others in the patient care } \\
\text { process, including interdependent } \\
\text { decision making and management } \\
\text { among health team members as } \\
\text { well as with patients, significant } \\
\text { others, and community members. } \\
\text { (IOM, HF0) }\end{array}$ \\
\hline $\begin{array}{l}\text { 2.1.2 In collaboration with health } \\
\text { team members determines when } \\
\text { and how to integrate evidence- } \\
\text { based practice into interprofessional } \\
\text { team care (including appraises the } \\
\text { evidence for interventions for the } \\
\text { validity and usefulness of the evi- } \\
\text { dence in the context of a particular } \\
\text { patient or population). (IOM) }\end{array}$ & $\begin{array}{l}2.2 .2 \text { Identifies errors and hazards in } \\
\text { care from the perspectives of each } \\
\text { profession and implements basic } \\
\text { safety design principles. (IOM) }\end{array}$ & $\begin{array}{l}2.3 .2 \text { Understands roles of health } \\
\text { team members in decisions related } \\
\text { to working from a framework of } \\
\text { interprofessional, collaborative, } \\
\text { patient-centred care. (HF0) }\end{array}$ \\
\hline $\begin{array}{l}\text { 2.1.3 Recognizes shared decision- } \\
\text { making in ways that are consistent } \\
\text { with patient or population safety } \\
\text { and risk management. }\end{array}$ & $\begin{array}{l}2.2 .3 \text { Facilitates interprofessional } \\
\text { care by searching for, retrieving, and } \\
\text { managing electronic data from } \\
\text { health informatics sources in order } \\
\text { to make discipline-specific as well as } \\
\text { interprofessional team decisions. } \\
\text { (IOM) }\end{array}$ & \\
\hline
\end{tabular}

Note: Competencies without an identified source were developed by the Advisory Board and Extramural Review Panel.

(i.e., demonstration of what has been learned) and performance competencies (demonstration of learning in situations of healthcare planning and delivery). These efforts were always performed in the context of developing a competency framework that made sense but also one that was amenable to teaching-learning environments for healthcare students and practitioners. Furthermore, we believe strongly in evidence-based education and so wanted to evaluate our Core Competency Framework within a rigorous test bed.

With the phase of competency development complete, the second phase of scenario development was undertaken. Building on the Interprofessional Core Competency Framework, we started the process of analyzing the ways this type of framework could be translated into what we call learning maps. Learning maps are then translated into learning activities that have associated learning resources and learning outcome assessments. One category of learning activities is interactive videos that portray interprofessional care. The scenarios portrayed in the videos are selected for their educational value for helping students and practitioners under- 
73

Development of Competencies in IP Healthcare

Tashiro, Byrne, Kitchen, Vogel, \& Bianco
Journal of Research in Interprofessional Practice and Education

Vol. 2.1

July, 2011
Table 6

\section{Respect}

\begin{tabular}{|c|c|c|}
\hline \multicolumn{3}{|l|}{ Competency domain: 3.0 Respect } \\
\hline 3.1 Team functioning & $\begin{array}{l}3.2 \text { Assessment, planning, } \\
\text { and intervention }\end{array}$ & 3.3 Patient-centred care \\
\hline $\begin{array}{l}\text { 3.1.1 Respects complementary } \\
\text { nature of health team members' } \\
\text { scopes of practice. (HFO) }\end{array}$ & $\begin{array}{l}\text { 3.2.1 Learns about other health } \\
\text { team members' expertise, back- } \\
\text { ground, knowledge, and values in } \\
\text { assessing a patient and planning } \\
\text { that patient's care. (IOM) }\end{array}$ & $\begin{array}{l}\text { 3.3.1 Assesses needs and plans care } \\
\text { as a health team in ways that } \\
\text { identify and respect the differences, } \\
\text { values, and preferences of health } \\
\text { team members as well as of } \\
\text { patients, their significant others, } \\
\text { and community members. (IOM) }\end{array}$ \\
\hline $\begin{array}{l}\text { 3.1.2 Defines and clarifies roles and } \\
\text { responsibilities of different } \\
\text { professions in a health team, the } \\
\text { patient, the patient's significant } \\
\text { others, and community members. }\end{array}$ & $\begin{array}{l}\text { 3.2.2 Understands the specific } \\
\text { contributions that each profession } \\
\text { brings to the patient's overall care. }\end{array}$ & $\begin{array}{l}\text { 3.3.2 Understands and clarifies, } \\
\text { where appropriate, how each } \\
\text { profession, the patient, and the } \\
\text { patient's significant others con- } \\
\text { tribute to optimal patient care (or } \\
\text { optimal population health in } \\
\text { community health activities). }\end{array}$ \\
\hline $\begin{array}{l}\text { 3.1.3 Communicates acceptance for } \\
\text { each discipline's perspective during } \\
\text { team meetings and/or interprofes- } \\
\text { sional exchanges during the patient } \\
\text { care process. }\end{array}$ & & \\
\hline
\end{tabular}

Note: Competencies without an identified source were developed by the Advisory Board and Extramural Review Panel.

stand the complexities of interprofessional care. However, the videos do not always show best practices in interprofessional care planning and delivery. Rather, these videos are "snapshots" into the real world, where healthcare professionals do not always work well together; where patient care may be complex and confusing; and where practitioners have to figure out ways to work with colleagues, patients, and patients' significant others to assess needs, plan care, and implement evidence-based practices that optimize patient outcomes.

Independent filmmakers from Los Angeles and Toronto were recruited to film the scenes of each simulation. Professional actors were recruited to play the roles of patients and families, and key healthcare provider roles were played by healthcare professionals to ensure accurate portrayals. A software development team used a research-driven model to study usability of the interfaces within the virtual world and to create a software application that health sciences students could enter and in which they could engage in interprofessional, collaborative, patient-centred care. The teaching-learning-assessment environment that was created is now undergoing rigorous study to determine if the simulations are effective at improving undergraduate health sciences students' interprofessional care competencies. The competency assessment engine allows exploration of both conceptual and performance competencies.

A research team that included educational researchers, simulation developers, 
74

Development of Competencies in IP Healthcare

Tashiro, Byrne, Kitchen, Vogel, \& Bianco
Journal of Research in Interprofessional Practice and Education

Vol. 2.1

July, 2011
Table 7

\section{Communications}

\begin{tabular}{|l|l|l|}
\hline \multicolumn{3}{|l|}{ Competency domain: $\mathbf{4 . 0}$ Communications } \\
\hline 4.1 Team functioning & $\begin{array}{l}\text { 4.2 Assessment, planning, } \\
\text { and intervention }\end{array}$ & 4.3 Patient-centred care \\
\hline $\begin{array}{l}\text { 4.1.1 Demonstrates basic communi- } \\
\text { cation skills within health teams as } \\
\text { well as with patients and their } \\
\text { significant others, including active } \\
\text { listening, conflict resolution, and } \\
\text { providing constructive feedback. } \\
\text { (IOM) }\end{array}$ & $\begin{array}{l}\text { 4.2.1 Communicates with other } \\
\text { health team members in a shared } \\
\text { language, even when members are } \\
\text { contributing to patient care from dif- } \\
\text { ferent physical locations and health- } \\
\text { care sectors that include healthcare } \\
\text { agencies using different terminolo- } \\
\text { gies. (IOM) }\end{array}$ & $\begin{array}{l}\text { 4.3.1 Involves a patient and their } \\
\text { significant others in communica- } \\
\text { collaborative patient-centred care. } \\
\text { (HF0) }\end{array}$ \\
\hline $\begin{array}{l}\text { 4.1.2 Ensures that accurate and } \\
\text { timely information reaches those } \\
\text { who need the information. (I0M) }\end{array}$ & $\begin{array}{l}\text { 4.2.2 Develops collaborative commu- } \\
\text { nication strategies using informa- } \\
\text { tion technology such as email, } \\
\text { instant messaging, listservs, and } \\
\text { file transfers. (IOM) }\end{array}$ & $\begin{array}{l}\text { 4.3.2 Demonstrates communication } \\
\text { skills with the patient, their signifi- } \\
\text { cant others, community members, } \\
\text { and formal and informal support } \\
\text { systems. }\end{array}$ \\
\hline & $\begin{array}{l}\text { 4.2.3 Understands security } \\
\text { protections and directly addresses } \\
\text { ethical and legal issues related to } \\
\text { use of information technology in } \\
\text { interprofessional practice. (IOM) }\end{array}$ & \\
\hline & $\begin{array}{l}\text { 4.2.4 Demonstrates accurate } \\
\text { documentation of patient data into } \\
\text { health records during interprofes- } \\
\text { sional care, working within } \\
\text { appropriate legal, risk, and } \\
\text { professional parameters. }\end{array}$ & \\
\hline
\end{tabular}

Note: Competencies without an identified source were developed by the Advisory Board and Extramural Review Panel.

and clinicians created an educational simulation in an Adobe Flex environment that could be deployed over the Internet. To help provide basic educational compartmentalization, the research team decided to build one simulation for each of the six competency domains. Furthermore, within each simulation, a specific scenario was created to address each of the cross-cutting themes. As a more specific example of this process, consider Table 4, which shows competency domain 1: problem solving. Note that this table contains the three cross-cutting themes derived during our developmental analysis:

Within each cross-cutting theme are specific competencies that expert panels devel-

\begin{tabular}{|l|l|l|}
\hline 1.1 Team functioning & $\begin{array}{l}1.2 \text { Assessment, planning, } \\
\text { and intervention }\end{array}$ & 1.3 Patient-centred care \\
\hline
\end{tabular}

oped and evaluated as observable and measurable competencies that a student could demonstrate. Using the learning map process described above, the research 
75

Development of Competencies in IP Healthcare

Tashiro, Byrne, Kitchen, Vogel, \& Bianco
Journal of Research in Interprofessional Practice and Education

Vol. 2.1

July, 2011
Table 8

Shared knowledge

\begin{tabular}{|c|c|c|}
\hline \multicolumn{3}{|c|}{ Competency domain: 5.0 Shared knowledge } \\
\hline 5.1 Team functioning & $\begin{array}{l}5.2 \text { Assessment, planning, } \\
\text { and intervention }\end{array}$ & 5.3 Patient-centred care \\
\hline $\begin{array}{l}\text { 5.1.1 Acts as an effective member of } \\
\text { a health team and improves the } \\
\text { quality of one's own performance } \\
\text { through self-assessment and } \\
\text { personal change. (IOM) }\end{array}$ & $\begin{array}{l}\text { 5.2.1 Incorporates the multiple } \\
\text { determinants of health into } \\
\text { interprofessional care. (Pew) }\end{array}$ & $\begin{array}{l}\text { 5.3.1 Understands roles of external } \\
\text { agencies and patient input in the } \\
\text { context of making appropriate } \\
\text { consults/referrals as part of patient's } \\
\text { treatment plan. }\end{array}$ \\
\hline $\begin{array}{l}\text { 5.1.2 Participates in interprofes- } \\
\text { sional education activities } \\
\text { (e.g., Grand Rounds, journal } \\
\text { article presentations, and case } \\
\text { presentations). }\end{array}$ & $\begin{array}{l}\text { 5.2.2 Applies knowledge of emerg- } \\
\text { ing scientific and care-related } \\
\text { research into interprofessional care. } \\
\text { (Pew) }\end{array}$ & $\begin{array}{l}\text { 5.3.2 Continually applies, measures, } \\
\text { and evaluates quality of interprofes- } \\
\text { sional care in terms of: } 1 \text { ) structure } \\
\text { or the inputs into the system (such } \\
\text { as patients, staff, and environ- } \\
\text { ments); } 2 \text { ) process (e.g., the interac- } \\
\text { tions between clinicians as well as } \\
\text { among clinicians, patients, and } \\
\text { patient's significant others); and } \\
\text { 3) outcomes or evidence about } \\
\text { changes in patient's health status in } \\
\text { relation to patient and community } \\
\text { needs. (IOM) }\end{array}$ \\
\hline $\begin{array}{l}\text { 5.1.3 Shares knowledge gained from } \\
\text { conferences and evidence-based } \\
\text { research with health team and } \\
\text { understands the implications of } \\
\text { such new knowledge on team } \\
\text { dynamics and/or patient care. }\end{array}$ & $\begin{array}{l}5.2 .3 \text { Integrates evidence-based } \\
\text { practice and relevant research into } \\
\text { the interprofessional implementa- } \\
\text { tion of the patient care process. }\end{array}$ & \\
\hline
\end{tabular}

Note: Competencies without an identified source were developed by the Advisory Board and Extramural Review Panel.

team discussed real-world clinical scenarios that would allow students to engage in "problem solving" within the simulation and demonstrate the 12 competencies listed in Table 4.

After reviewing different clinical cases, the research team decided to build a simulation related to the competency domain of problem solving around a motor vehicle accident victim who was also suffering from substance abuse and addiction as well as HIV infection. The three scenarios within this simulation were then designed to represent different stages of care for this patient. Scenario 1 focused on problem solving within the cross-cutting theme of team functioning during patient care related to pain management. Scenario 2 examined problem solving related to assessment, planning, and intervention while dealing with issues related to verbal abuse by the patient. Scenario 3 explored the complexities of problem solving related to patient-centred care as a health team of caregivers began working through collaborative patient-centred care for this patient. We will not detail each 


\section{JRIPE}

76

Development of Competencies in IP Healthcare

Tashiro, Byrne, Kitchen, Vogel, \& Bianco
Journal of Research in Interprofessional Practice and Education

Vol. 2.1

July, 2011
Table 9

\section{Team participation}

\begin{tabular}{|c|c|c|}
\hline \multicolumn{3}{|c|}{ Competency domain: 6.0 Team participation } \\
\hline 6.1 Team functioning & $\begin{array}{l}6.2 \text { Assessment, planning, } \\
\text { and intervention }\end{array}$ & 6.3 Patient-centred care \\
\hline $\begin{array}{l}\text { 6.1.1 Maintains flexibility in roles } \\
\text { within legally defined scopes of } \\
\text { practice. (UMinn) }\end{array}$ & $\begin{array}{l}\text { 6.2.1 Demonstrates interdependent } \\
\text { strategies for planning and imple- } \\
\text { menting care. (UMinn) }\end{array}$ & $\begin{array}{l}\text { 6.3.1 Helps facilitate interprofes- } \\
\text { sional care conferences that recog- } \\
\text { nize contributions of health team } \\
\text { members, patients, and patient's } \\
\text { significant others. (HFO) }\end{array}$ \\
\hline $\begin{array}{l}\text { 6.1.2 Knows and demonstrates } \\
\text { mechanisms for conflict resolution. } \\
\text { (UMinn) }\end{array}$ & $\begin{array}{l}\text { 6.2.2 Establishes common patient } \\
\text { and team goals in assessment and } \\
\text { planning. (UMinn) }\end{array}$ & $\begin{array}{l}\text { 6.3.2 Demonstrates understanding } \\
\text { of complementary nature of each } \\
\text { professional's input as well as input } \\
\text { from the patient and their signifi- } \\
\text { cant others in care planning and } \\
\text { implementation. }\end{array}$ \\
\hline 6.1.3 Collaborates willingly. (UofT) & & $\begin{array}{l}\text { 6.3.3 Demonstrates openness to } \\
\text { trust of health team members as } \\
\text { well as of patients and their signifi- } \\
\text { cant others. (UofT) }\end{array}$ \\
\hline \multicolumn{3}{|l|}{$\begin{array}{l}\text { 6.1.4 Shares responsibilities for } \\
\text { health team actions. (UMinn) }\end{array}$} \\
\hline \multicolumn{3}{|l|}{$\begin{array}{l}\text { 6.1.5 Develops evaluative feedback } \\
\text { related to planning and implement- } \\
\text { ing interprofessional care. (UMinn) }\end{array}$} \\
\hline $\begin{array}{l}\text { 6.1.6 Demonstrates basic group } \\
\text { skills in collaboration, negotiation, } \\
\text { delegation, time management, } \\
\text { and assessment of health team } \\
\text { dynamics. (IOM) }\end{array}$ & & \\
\hline
\end{tabular}

Note: Competencies without an identified source were developed by the Advisory Board and Extramural Review Panel.

cross-cutting theme's scenario development, but simplify here and state that a scenario is composed of scenes, just like a segment of a feature film. The research team looked at each of the three scenarios for this motor accident victim and decided how to develop the scenes that could be used to help students develop problem solving competencies. You can see in Table 4 that the competencies under team functioning include:

- 1.1.1 knows scopes of professional practice (HFO);

- 1.1.2 defines responsibilities and roles of different professions (HFO);

- 1.1.3 contributes to interprofessional problem-solving (HFO);

- 1.1.4 coordinates and integrates care processes that reflect excellence, continuity, and reliability of interprofessional care provided (IOM). 
77

Development of Competencies in IP Healthcare

Tashiro, Byrne, Kitchen, Vogel, \& Bianco

Journal of Research in Interprofessional Practice and Education

Vol. 2.1

July, 2011
Using real clinical encounters similar to the simulated case, the research team delineated the learning activities related to team functioning and to four competencies within this cross-cutting theme. The learning activities for the team functioning scenario included patient records, a video of patient care by multiple caregivers, and an analysis of interprofessional care perspectives relevant to this type of patient. The learning resources were developed for this scenario to provide students with educational scaffolding to figure out scopes of practice, responsibilities and roles, models of interprofessional problem solving, and strategies for co-ordinating and integrating care processes within an interprofessional framework. Such scaffolding was provided as access within the simulation to: 1) a library of hyperlinks that opened to the scopes of practice of different caregivers; 2) papers and reports on interprofessional care; and 3) the Interprofessional Core Competency Framework. Authentic learning outcomes assessments were then designed around measures that would allow a faculty member to determine if a student achieved each of the four competencies that were the focus of the team functioning cross-cutting theme in the competency domain of problem solving.

The research team worked on each scenario for this competency domain of problem solving. All of the learning activities were developed so that they could be embedded within the simulation. All of the learning resources were collected and loaded into the simulation. Learning activities were then evaluated to determine if they would allow student engagement that could be observed and measured. The learning outcomes assessment for each learning activity were designed and reviewed. At this point, the scenes of each scenario were scripted, and film crews were brought in to film the video portions of the learning activities. The film crews worked with the research team to produce screenplays for each scenario and then proceeded through filming and editing. All of the learning objects were then assembled within the Adobe Flex environment, studied for usability and accessibility, and finally deployed from a server within the University of Ontario Institute of Technology.

This process of moving from competencies to patient cases to learning maps to simulations to scenarios was repeated for each competency domain. You can see in Tables 4 through 9 there are quite a large number of specific competencies under the respective cross-cutting themes that were set up for each domain. Interestingly, this process allowed additional review of the competencies listed in Tables 4 through 9. In addition, we were able to critique whether the competencies were the best fit for the respective domain-theme cell of our framework. We believe that the learning map development process provides an additional type of validation for placement of competencies from the literature within the Interprofessional Core Competency Framework we developed.

We now have six patient simulations, each of which has three scenarios providing a variety of options to demonstrate interprofessional care. The patients in these simulations were chosen for their complexity and realism in Canadian healthcare systems, representing various ages and stages, within the hospital setting, the community setting, and home. The development of these simulations will be discussed in a subsequent paper. 
78

Development of Competencies in IP Healthcare

Tashiro, Byrne, Kitchen, Vogel, \& Bianco

Journal of Research in Interprofessional Practice and Education

Vol. 2.1

July, 2011
The final phase of this research program will be to evaluate undergraduate student development of the competencies within our Interprofessional Core Competency Framework. Each scene of each simulation has been developed into an interactive teaching-learning-assessment environment, using state-of-the-art design for computer-based virtual worlds containing interactive videos of each scene around which were nested a variety of learning resources, learning activities, and competency assessments. Embedded in the interactive videos, learning resources, and learning activities are opportunities for students to demonstrate the competencies associated with the respective scene. The competency assessment engine was built around research on cognitive taxonomies and a multi-attribute latent class model of learning outcomes assessment [40-43].

However, we want to point out that as our work on a new type of evidence-based teaching-learning-assessment environment progressed, we re-integrated earlier studies on theories of cognition that had begun with National Institutes of Health funding to Tashiro in 2000 (NINR 1-43-NR05102-01). Specifically, we studied how cognitive and learning sciences inform instructional design in the situated experience of an educational engagement. Since we were working on simulations, we focused on the theory and praxis within these types of environments, drawing on the emerging literature related to educational simulations and serious games. Patel and colleagues [37] examined how cognition will be shaped by the situated encounters in educational environments, which are dynamic and strongly influenced by social contexts and by a diverse array of other elements in the setting, such as technology, as well as temporal and spatial heterogeneity in a simulated or game environment. We adapted Patel's framework to our work on interprofessional simulations and an important breakthrough resulted from re-examination of possible cognitive frameworks for instructional design in interprofessional education.

Patel's work led us to ask what would happen if different combinations of aesthetics, mechanics, and dynamics for an educational simulation led to different types of reasoning, and if so, what might be the results of such reasoning. Here, we are using the terms from the literature on gaming: 1) aesthetics denotes the sense of the fictional world created by graphics and sound, 2) mechanics denotes the underlying programming that provides fictional interactions within the virtual setting; and 3) dynamics is a term used to capture the potential interactions possible in a game and the emergence of end users' engagement within such interactions. So, we had to struggle with how and why aesthetics, mechanics, and dynamics could shape learning and development of cognitive processes leading to patterns of students' reasoning [38].

During use-case experiments, we realized that a very sophisticated virtual world might be valuable to examine differences between cognitive theories and their projected educational strategies for more individualistic structured learning (the adaptive character of thought and cognitive load theories) or for what educators call constructivist learning (the cognitive flexibility theory and situated learning theories) $[37,38]$. We also realized that educational simulation developers have generally not mapped the aesthetics, mechanics, and dynamics of their games to a 
79

Development of Competencies in IP Healthcare

Tashiro, Byrne, Kitchen, Vogel, \& Bianco

Journal of Research in Interprofessional Practice and Education

Vol. 2.1

July, 2011 particular theoretical framework or a synthesis of frameworks that had some empirical foundation.

Continuing work on cognition and learning development in educational simulations led us to re-evaluate the types of learning outcomes and competencies that would be foundational for authentically measuring conceptual and performance competencies in interprofessional collaborative patient-centred care (IPCPC). Our early prototypes revealed that educational simulations for IPCPC could be built with potential opportunities to demonstrate competencies embedded in the simulated environment so that a student's knowledge could be demonstrated during interactions in the simulation, and their activities monitored to see if competencies were achieved. A very important advancement was our discovery of how to trace the development of misconceptions, using data mining methods to analyze students' choices as well as their educational outcomes while engaging within serious games (e.g., conceptual competencies that represent a thorough understanding of a knowledge and/or skills domain, and performance competencies, such as those competencies in which knowledge is acted on through a variety of decisions or when skills are implemented in the real world or some very close simulation of the real world) $[37,38]$.

Interestingly, and as is true in all research, our progress in the areas described above opened another door of inquiry. Specifically, we conducted a comprehensive literature review of educational simulations and serious games [38], and there were still eight important gaps in our knowledge about effective use of all educational materials, although we contextualize these gaps within educational simulations: 1) how does a simulation or serious game enhance disposition to engage in learning; 2) what are the relationships between the level of realism in a simulation or game and learning outcomes; 3 ) how do you define the threshold of experience within a game or simulation that leads to measurable learning outcomes; 4) what are the cognitive processes developed during learning while working within a game or simulation; 5) in what knowledge domains is learning being retained and how stable is the retention; 6) what is the disposition to act on the knowledge gained during work within a simulation; 7) how well can the knowledge gained within a game or simulation be transferred; and, 8) what are the differences in learning that manifest as conceptual competencies and performance competencies.

We are now pursing studies related to these eight gaps with a research grant from the Social Sciences and Humanities Research Council of Canada. A particular focus of this research is the transition from conceptual competencies to performance competencies as learning is expressed as behaviours. In this work, we have been examining how the IPCPC simulations can be built around both theories of cognition and theories of behavioural change [44,45].

Furthermore, this new research extends the learning maps developed from our framework for competencies in interprofessional healthcare for use in health sciences educational programs. The most important advance is related to being able to rapidly modify the IPCPC simulation model to accommodate different models of cognition as well as different models of behavioural change. We can also track 
80

Development of Competencies in IP Healthcare

Tashiro, Byrne, Kitchen, Vogel, \& Bianco
Journal of Research in Interprofessional Practice and Education

Vol. 2.1

July, 2011 exactly where a student moves within the simulation as well as how much time is spent in educational activities in each simulation venue. We are now implementing this research, and initial studies will focus on students in a college-to-university transition program, the Bachelor of Allied Health Sciences at UOIT.

\section{Conclusion}

We have been able to create a peer-reviewed core competency framework for interprofessional education. This framework has strengthened earlier frameworks in terms of using a taxonomy of domains and cross-cutting themes that facilitate the classification of competency areas. The classifications were then mapped to learning objectives that would need to be mastered in order to demonstrate each competency. Learning objectives were mapped to learning opportunities and each learning opportunity was developed as a suite of learning activities in which a student could engage. For each learning activity, we selected learning resources that could provide as-needed learning resources for students. Finally, we developed the first set of learning outcomes assessments and are now studying their construct validity.

HETRU researchers then built an educational simulation for interprofessional care, using the aforementioned expanded learning map to create a sensible educational environment that layered software algorithms within the simulation to monitor how students actually use the simulation. We note here that we have simplified the description of this new type of learning environment. However, HETRU researchers have been studying the complexity of building educational materials within an evidence-based framework. Johnson and Tashiro [4], Garcia-Ruiz, Tashiro, Kapralos and Vargas Martin [38], Tashiro [46], and Tashiro and Dunlap [47] examined some of the difficulties in studying educational outcomes and competency measurements in the health sciences, including an ethical analysis of the failure of faculty and publishers of educational materials to develop, select, and use instructional materials that have a strong empirical base for improving educational outcomes. Ongoing work will lead to the creation of evidence-based learning environments and measures of complex competencies for interprofessional care.

\section{Acknowledgements}

The authors would like to thank the Interprofessional Care/Education Fund, HealthForceOntario for funding this project.

\section{References}

1. Canadian Health Information Management Association. (2009). Fundamentals of health information management. Ottawa, ON: CHA Press.

2. United States National Research Council. (2009). Computational technology for effective health care: Immediate steps and strategic directions. Washington, DC: National Academy Press.

3. Kabene, S.M., Orchard, C., Howard, J.M., Soriano, M., \& Leduc, R. (2006). The importance of. human resources management in health care: A global context. URL: hattp://www. Iresources-health.com/content/4/1/20!' [January 20, 2008].

4. Johnson, K., \& Tashiro, J. (2011). Interprofessional care and health care complexity: Factors shaping human resources effectiveness in health information management. In Kabene, S.M. (Ed.), Human resources in healthcare, health informatics and healthcare systems, (pp. 250-280). Hershey, PA: IGI Global. 
81

Development of Competencies in IP Healthcare

Tashiro, Byrne, Kitchen, Vogel, \& Bianco

Journal of Research in Interprofessional Practice and Education

Vol. 2.1

July, 2011
5. Vendome Group. (2007). Optimizing clinical workflows: Technology trends to improve patient care: A health care informatics survey. New York: Vendome Group, LLC.

6. Vendome Group. (2008). Trends in technology for nurses: A health care informatics survey. New York: Vendome Group, LLC.

7. Canadian Interprofessional Health Collaborative. (2007). Interprofessional education and core

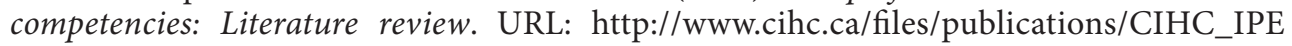
L-LitReview_May07.pdfín [October 31, 2007].

8. Barker, K.K., \& Oandasan, I. (2005). Interprofessional care review with medical residents: lessons learned, tensions aired: A pilot study. Journal of Interprofessional Care 2005, 19(3), 207-214.

9. Barker, K.K., Bosco, C., \& Oandasan, I.F. (2005). Factors in implementing Interprofessional education and collaborative practice initiatives: Findings from key informant interviews. Journal of Interprofessional Care, (Suppl 1), 166-176.

10. Health Canada. (2004). Interdisciplinary education for a collaborative patient-centered practice. Research and findings report. Ottawa, ON: Health Canada.

11. HealthForceOntario. (2007). Interprofessional care: A blueprint for action in Ontario. URL:'inttp://

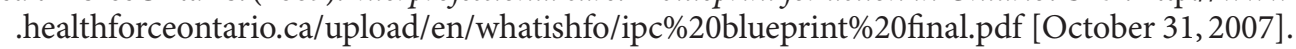

12. United States Institute of Medicine. (2000). To err is human: Building a safer health care system. Washington, DC: National Academy Press.

13. United States Institute of Medicine. (2003). Health profession education: A bridge to quality. Washington, DC: National Academies Press.

14. United States Institute of Medicine. (2005). Crossing the quality chasm: A new health system for the $21^{\text {st }}$ century. Washington, DC: National Academy Press.

15. Mead, N., \& Bower, P. (2000). Patient centeredness: A conceptual framework and review of the empirical literature. Social Science in Medicine, 51, 1087-1110.

16. Beach, M.C., \& Inui, T. (2006). Relationship-centered care: A constructive reframing. Journal of General Internal Medicine, 21(Suppl 1), S3-S8.

17. Engel, G.L. (1977). The need for a new medical model: A challenge for biomedicine. Science, 196, 129-136.

18. Herbert, C.P. (2005). Changing the culture: Interprofessional education for collaborative patientcentered practice in Canada. Journal of Interprofessional Care, 19(Suppl 1), S1-S4.

19. Byrne, C. (1991). Interdisciplinary education in health sciences. Education Pedagogue, 3(3), 1-8.

20. Health Canada. (2003). First Ministers Accord on Health Care Renewal. Ottawa, ON: Health Canada.

21. Reeves, S., Russell, A., Zwarenstein, M., Kenaszchuz, C., Conn, L.G. et al. (2007). Structuring communication relationships for interprofessional teamwork (SCRIPT): A Canadian initiative aimed at improving patient-centered care. Journal of Interprofessional Care, 21(1), 111-114.

22. Saltvedt, I., Mo, E.S., Fayers, P., Kaasa, S., Sletvold, O. (2002). Reduced mortality in treating acutely sick, frail, older patients in a geriatric and management unit: A prospective randomized trial. Journal of American Geriatric Society, 50, 792-798.

23. Boult, C., Boult, L.B., Morishita, L., Dowd, B., Kane, R.L. et al. (2001). A randomized clinical trial of outpatient geriatric evaluation and management. Journal of American Geriatric Society, 49, 351-359.

24. Kasper, E.K., Ge rstenglith, G., Hefer, G., Van Anden, E., Brinker, J.A. et al. (2002). A randomized trial of the efficacy of multidisciplinary care in heart failure outpatients at high risk of hospital readmission. Journal of American College of Cardiology, 39, 471-480.

25. Rogowski, J.A., Horbar, J.D., Pisek, P.E., Baker, L.S., Deterding, J. et al. (2001). Economic implications of neonatal intensive care unit collaborative quality improvement. Pediatrics, 107, 23-29.

26. Parsell, G., \& Bligh, J. (1998). Interprofessional learning. Postgraduate Medical Journal, 74, 89-95.

27. College of Nurses of Ontario. (2005). Canadian nurse practitioner core competency framework. URL:

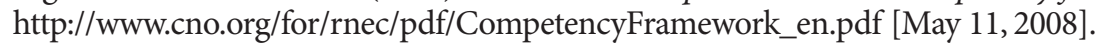

28. Barr, H. (1998). Competent to collaborate: Towards a competency-based model for interprofessional education. Journal of Interprofessional Care, 12(2), 181-186.

29. Barr, H. (2005). Interprofessional education. Today, yesterday, and tomorrow: A review. UK Centre for the Advancement of Interprofessional Education. Oxford, UK: Blackwell Publishing, Ltd.

30. American Council on Pharmaceutical Education. (1997). Accreditation standards and guidelines for the professional program in pharmacy leading to the Doctor of Pharmacy degree. URL:

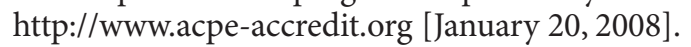

31. O'Neil, E.H. (1998). Recreating health professional practice for a new century: The fourth report of the Pew Health Professions Commission. San Francisco: Pew Professions Commission. 
JRIPE

82

Development of Competencies in IP Healthcare

Tashiro, Byrne, Kitchen, Vogel, \& Bianco

\section{Journal of Research in Interprofessional Practice and Education}

32. University of Minnesota. (1996). A report by the Academic Health Center Task Force on interdiscipli-

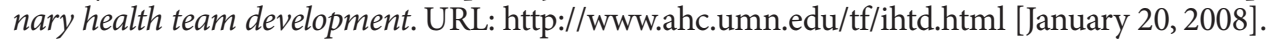

33. Wood, V., Flavell, A., Vanstolk, D., Bainbridge, L., \& Nasmith, L. (2009). The road to collaboration: Developing an Interprofessional competency framework. Journal of Interprofessional Care, 23(6), 621-629.

34. Guided Interprofessional Field Study. (2007)._Interprofessional Collaborative Practice: Foundational Level. URL:ihttp://wwww.in-bacca/project/gif.phpi [May 20, 2007].

35. Odegard, P.S., Robins, L., Murphy, N., Belza, B., Brock, D. et al. (2009). Interprofessional initiatives at the University of Washington. American Journal of Pharmaceutical Education, 73(4), article 63.

36. Robins, L., Brock, D.M., Gallagher, T., Kartin, D., Lindhorst, T. et al. (2008). Piloting team simulations to assess Interprofessional skills. Journal of Interprofessional Care, 22(3), 325-328.

37. Patel, V.L., Yoskowitz, N.A., Arocha, J.F., \& Shortliffe, E.H. (2009). Cognitive and learning sciences in biomedical and health instructional design: a review with lessons for biomedical informatics education. Journal of Biomedical Informatics, 42, 176-197.

38. Garcia-Ruiz, M.A., Tashiro, J., Kapralos, B., \& Vargas Martin, M. (2011). Crouching tangents, hidden danger: Assessing development of dangerous misconceptions within serious games for healthcare education. In Hai-Jew, S. (Ed.), Virtual immersive and 3D learning spaces: Emerging technologies and trends, (pp. 269-306). Hershey, PA: IGI Global.

39. University of Toronto. (2007). Health professional collaborator competencies. URL: 'inhttp:[/!

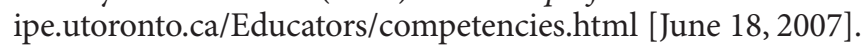

40. Anderson, L., Krathwohl, D. (2001). A taxonomy for learning, teaching, and assessing. New York: Longman.

41. United States National Research Council. Bransford, J.D., Brown, A.L., Cocking, R.R. (Eds.). (2000). How people learn: Brain, mind, experience, and school. Washington, DC: National Academy Press.

42. United States National Research Council. (2001). Knowing what students know: The science and design of educational assessment. Washington, DC: National Academy Press.

43. United States National Research Council. (2005). How students learn: History, mathematics, and science in the classroom. Washington, DC: National Academies Press.

44. Martin, L.R., Haskard-Zolnierek, K.B., DiMatteo, M.R. (2010). Health behavior change and treatment adherence: Evidence-based guidelines for improving healthcare. New York: Oxford University Press.

45. DiMatteo, M.R., \& DiNicola, D.D. (1982). Achieving patient compliance. New York: Pergamon Press.

46. Tashiro, J. (2009). Ethical analysis of publisher and faculty roles in building and using electronic educational products. Journal of Electronic Commerce in Organizations, 7(1), 1-17.

47. Tashiro, J., \& Dunlap, D. (2008). The impact of realism on learning engagement in educational games. Association of Computing Machinery Digital Library, 113-120. doi: 978-159593-943$2 / 07 / 011$.
Journal of Research in Interprofessional Practice and Education

Vol. 2.1

July, 2011 